\title{
Penggunaan Media Busy Book Pada Anak Usia Dini dalam Meningkatkan Kemampuan Kognitif Berhitung
}

\section{Rifka Toyba Humaida}

Universitas Sunan Kalijaga, Yogyakarta, Indonesia rifkanirhan66@gmail.com

\section{Muhammad Zainal Abidin}

STAIT Yogyakarta, Yogyakarta, Indonesia zabid27@gmial.com

\begin{abstract}
The Using of Busy Book Media for Introduction to Calculation Ability in Early Childhood. This study aims to describe how the application of busy book media in improving children's cognitive abilities in instilling the concept of arithmetic to children in Kindergarten Thoyyibah. This type of research uses descriptive qualitative methods with the research subjects, namely: a group of children in TK Thoyyibah. Data collection techniques that researchers use are observation, interviews, and documentation. The results of research in this study regarding the use of busy book media in increasing cognitive ability to count and encouraging the development of various intellectual potentials, such as mathematics, namely the numeracy ability of children in matching, sorting, comparing so that their numeracy skills develop optimally according to age stages.
\end{abstract}

Keywords: Busy book; cognitive; counting

Abstrak: Penelitian ini bertujuan untuk mendeskripsikan bagaimana penerapan media busy book dalam meningkatkan kemampuan kognitif anak dalam menanamkan konsep berhitung kepada anak di TK Thoyyibah jenis Penelitian ini mengunakan metode kualitatif deskriptif dengan subjek penelitian yaitu: Sekelompok anak di TK Thoyyibah. Teknik pengumpulan data yang peneliti gunakan adalah observasi, wawancara, dan dokumentasi. Hasil 
penelitian dalam penelitian ini mengenai penggunaan media busy book dalam meningkatkan kemampuan kognitif berhitung dan mendorong pengembangan berbagai potensi intelektual, seperti matematika yaitu kemampuan berhitung anak dalam mencocokan, mengurutkan, membandingkan sehingga kemampuan berhitung berkembang secra optimal sesuia dengan tahapan usia.

Kata kunci: Busy book, kognitif, berhitung.

\section{A. Pendahuluan}

Anak Usia Dini ialah sosok individu yang sedang menjalani suatu proses perkembangan dengan pesat dan fundamental bagi kehidupan selanjutnya. Anak usia dini berada pada rentang usia 0-8 tahun. Pada masa ini proses pertumbuhan dan perkembangan dalam berbagai aspek mengalami masa yang cepat dalam rentang perkembangan hidup manusia (Yuliani Nuraini Sujiono, 2013). Pendidikan anak usia dini merupakan dasar pertama Pendidikan utama untuk mengembangkan pribadi anak yang memiliki hubungan dengan karakter, kekuatan fisik, kemampuan kognitif, kecakapan Bahasa, seni, social emosional, spiritual, displin diri, social emosional, spiritual, displin diri, konsep diri dan kemandirian dari panca indera (Hasyim, 2015). Pendidikan anak usia dini yang memberikan fasilitas sarana dan pra-sarana untuk menumbuhkembangkan pertumbuhan bagi anak usia dini terutam aspek perkembangan individu anak. Dalam kegiatan pembelajaraan untuk anak usai dini pendidik seharusnya memiliki metode yang menyenangkan dan kreatif sehingga peserta didik mudah menerima apa yang kita sampaikan (Dwiyanti et al., 2019).

Aspek perkembangan Kognitif sangat penting untuk dikembangkan karena kognitif termasuk hal penting bagi sosok individual. Dalam ranah PAUD memiliki karakteristik pembelajraan dengan pengembangan kurikulum yang secara nyata berisikan dengan pengalaman belajar yang dijelaskan lewat permainan yang tentunya didasarkan pada potensi serta kemampuan anak. Pengembangan kualiatas PAUD di Indonesia dapak di laksanakan dengan mempraktikan reformasi Pendidikan. Pergantian pembelajaraan tradisional mengarah ke pembelajaran yang lebih meningkatkan aspek kognitif bisa 
disebut dengan reformasi pendidikan(Nurfadillah \& Rakhman, 2020), dalam pengembanagn kognitif sebagaimana dijelaskan UU 137 bahwasanya: a) belajar pemecahan masalah, yang mencakpu kemampuan memecahan maslah sederhana. b) berfikir logis, mencakup berbagai perbedaan, klasifikasi, pola, berinisiatif, berencana, dan mengenal sebab akibat. C) berfikir simbolik, mencakup kemampuan menegnal, menyebutkan, dan mengunakan konsep bilangan, menegnal huruf, serta mampu merepresentasikan berbagai benda dan imajinasinya dalam bentuk gambar. (Kementrian Pendidikan Nasional RI, 2014) aritmatika ialah suatu pembelajaraan untuk mengembangkan kemampuan berhitung, didalam kurikulum 2013 di dalam PAUD diberitahukan bahwasannya peserta didik harus mencapai beberapa hal yang termauk poin penting dalam susuna berhitung, ialah : mampu melafalkan lambing bilangan 1-10, mengunakan lambing bilangan untuk menghitung, dan mencocokan bilangan dengan lambing bilangan (Dwiyanti et al., 2019).

Pendidikan pra sekolah untuk anak usia dini keterampilan berhitung sangat dibutuhkan, bahwasannya berhitung termasuk bagian dari matematika yang sangat dibutuhkan untuk menumbuh kembangkan keterampilan kognitif anak usia dini terutam keterampilan berhitung dan konsep bilangan merupakan dasar Pendidikan kemampuan matematis. Di dalam Pendidikan anak usia dini yang bisa disebut dengan Pendidikan pra-sekolah dalam meningkatkan lima aspek perkembangannya seseorang pendidik harus se-kreatif mungkin menyiapkan media agar peserta didik mudah untuk menyerap pembelajaraan saat kegiatan belajar mengajar berlangsung. Sejalan dengan pendapat (Daryanto, 2011) media pembelajaraan adalah sesuatu yang mampu dipergunakan untuk menyampaikan pesan (bahan pembelajaraan) sehingga mampu merangsang perhatian, minat, fikiran, dan perasaan anak dalam kegiatan belajar agar mampu mencapai tujuan pembelajaraan. Untuk mempersiapkan individu agar dapat mengoptimalkan perkembangan anak yang paling utama ialah kemampuan individu. Media pembelajaraan adalah segala sesuatu yang dapat digunakan untuk menyalurkan pesan (bahan pembelajaraan) sehingga dapat merangsang perhatian, minat, fikiran, dan perasaan peserta didik dalam kegiatan belajar. 
Kemampuan berhitung merupakan kemampuan dalam mengunakan penalaran, logika dan angka-angka. Berhitung merupakan bagian dari matematika diperlukan untuk menumbuh kembangakan keterampilan berhitung yang sangat di perlukan dalam kehidupan sehari-hari terutama konsep bilangan yang merupakan dasar bagi pengembangan kemampuan matematis. Kegiatan dalam pembelajaraan pada aspek kognitif dalam kemampuan berhitung anak usia dini yang sesuai dengan standar tingkat pencapaian perkembangan anak (Kementrian Pendidikan Nasional RI, 2014) diantaranya ialah: anak mengenal benda berdasarkan fungsinya, mengunakan benda seagai permaianan simbolik, mengenal gejala sebab akibat yang terkait dengan dirinya, mengenal pola (abc-abc-abc) dan mengulanginya mengurutkan benda berdasarkan lima seriasi warna, anak melakukan pengamatan benda dengan gejala ras ingin tahu, mengenal konsep sederhana dalam kehidupan sehari-hari, dan mampu mengerti konsep banyak dan sedikit, konsep bilangan mengenal bilangan dll, kareana banyak standar yang harus dicapai dalam perkembangan kognitif, maka penelitian ini akan berfokus pada salah satu standar tngkat pencapaian perkembangan anak ialah konsep bilangan dengan indicator pencapaian minimal sebagai berikut : 1. Anak mampu membilang menyebut urutan bilanagn sampai 1-10 dengan benda-benda, 2. Anak mampu membilang dan menunjukan benda-benda (mengetahui konsep bilanagn dengn benda) 3. Menunjukan urutan bilangan sampai 1-10 dengan benda-benda. 4. Menghubungkan atau memasangkan lambang bilangan dengan benda-benda, 5. Menunjukan dua kumpulan yang sama, tidak sama, lebih banyak, dan lebih sedikit, sesuai dengan karakteristik anak usia dini yang menyukai dan lebih sedikit sesuai dengan karakteristik anak usia dini yang sangat menyukai dunia bermain, sebagai pendidik harus mampu menyajikan Pendidikan sengan sekreatif mungkin, bisa juga dengan mengunakan metode, strategi serta media pembelajaraan yang mampu menarik yang mampu menarik minat peserta didik dan yang sesuai karakteristik perkembangan anak usia dini (Ecular et al., 2010).

Aspek perkembangan sangat dibutuhkan untuk dioptimalakan yang salah satunya aspek perkemabnagan kognitif anak. Perkembangan kognitif pada anak usai dini dapat diartikan sebagai perubahan psikis yang berpengaruh terhadap 
kemampuan berfikir anak usia dini. Dengan kemamppuan berfikirnya, anak usai dini mampu mengeksplorasi dirinya sendiri, orang lain, hewan dan tumbuhan serta berbagai benda yang ada disekitarnya sehingga mereka dapat memperoleh berbagai pengetahuan (Wiyani, 2014). Sejalan dengan pendapat sujiono berpendapat bahwa kognitif ialah suatu proses berfikir, yaitu kemampuan individu untuk menghubungkan, menilai, dan mempertimbangkan suatu kejadian dan pristiwa selama anak bermain, anak menerima pengalaman baru, memanipulasi bahan, alat, berinteraksi dengan orang lain dan mulai merasakan dunia mereka (Yuliani Nuraini Sujiono, 2013b). Menurut Wasik (Wasik, 2008) konsep lambang bilangan merupakan suatu konsep yang berisikan angka yang dilambangakan berupa symbol bilangan. Dalam memeberi pembelajaraan kepada peserta didik harus disesuaikan dengan tema yang sedang berlangsung pada pembelajaraan anak sehingga sesuai dengan tingkan pembelajaraan dan mampu meningkatkan aspek enam perkembangan anak dini, ialah, aspek perkembagan motoric, sosial emosinal, kognitif, nilai agama moral, Bahasa dan seni. Anak-anak memiliki minat yang kuat dalam kearifan lingkungan seperti benda dan serta makhluk hidup yang ada disekitar kita seperti media bahan yang sangat bermanfaat dalam aspek perkembangan anak usia dini. Berdasarkan observasi awal pada kemampuan kognitif dalam membilang angka terdapat permaslahan dan belum berkembang Bulan Januari di TK Thoyyibah untuk kelas A yang berusia 4-5 diketahui bahwa kekampang dalam membilang dan berhitung masih belum berkembang focus, factor-faktor penyebab perkembanga anak dalam membilang di TK Thoyyibah yaitu: 1) pembelajarana hanya mengunakan buku, 2) penggunaan media yang kurang menarik, 3) anak kurang memahami dengan Langkah-langkah kegiatan. Dalam hal ini untuk mengopimalkan sebuah pembelajaraan untuk meningkatkan kognitif anak dalam membilang diberikan media busy book agar kemampuan meneganal konsep lambing bilanagna masing-masing anak berkemmbag dan terlatih. Peneliti memberikan sebuah media busy book yang melibatkan anak mempraktikan langsung dan belajar. Sehingga permasalahan yang melatar belakangi peneliti untuk menjalankan penelitian inbagaimana penggunaan media busy book dapat mengembangkan keterampilan kognitif dalam 
kemampuan berhitung aanak usia dini umur 4-5 tahun di TK Thoyyibah Bandar Lampung.

\section{B. Pembahasan}

\section{Metode}

Penelitian ini mengunakan pendekatan kualitaif deskritif Adapun metode yang digunakan dalam Model penelitian kualitatif ini disebut juga dengan kualitatif naturalistik yaitu model penelitian yang berorentasi pada kejadian ( fenomena) atau gejala yang bersifat alami. pelaksanaan nya memang terjadi secara alami, apa adanya dalam situasi normal yang tidak memanipulasi keadaan atau kondisinya, dan menekankan pada deskriftif secara alami (Arikunto, 2011). Sedangkan deskriptif adalah upaya menginterprestasikan kondisi-kondisi yang sekarang atau terjadi dengan kata lain untuk memperoleh informasi mengenai keadaan saat ini. Untuk mempermudah mengidentifikasi sumber data penulis mengklasifikasikannya menjadi 3 tingkatan huruf $p$ dari bahasa inggris yaitu (Arikunto, Suharsimi,2010). Person adalah sumber data yang bisa memberikan data berupa jawaban lisan melalui wawancara atau jawaban tertulis melalui angket. Dalam hal penelitian ini yang dimaksud person antara lain Kepala TK, Guru, Karyawan, dan Anak di di TK Thoyyibah Bandar Lampung. Place adalah sumber data yang menyajikan tampilan berupa keadaan diam dan bergerak, keduanya merupakan objek untuk penggunaan metode observasi. Dalam hal penelitian ini yang dimaksud place yakni lokasi penelitian dan kemampuan berhitung anak di TK Thoyyibah Bandar Lampung. Dimana keduanya merupakan hal yang akan diobservasi oleh peneliti. Paper adalah sumber data yang menyajikan tanda-tanda berupa huruf, angka, gambar, atau simbol-simbol lain, biasanya digunakan untuk metode dokumentasi. Dalam hal penelitian ini yang dimaksud dengan paper yakni literatur buku dan jurnal penelitian lain yang menunjang hasil penelitian maupun gambar dokumentasi pelaksanaan penelitian di TK Thoyyibah Bandar Lampung.

Penelitian ini dilakukan pada bulan Januari 2021 di TK THOYYIBAH Bandar Lampung. Subjek dalam penelitian ini yaitu peserta didik Kelas A usia 4-5 Tahun. Unit Analisis dalam penelitian ini difokuskan pada implikasi yang berperan secara riset ilmu pembelajaraan, yaitu implementasi pembelajaraan 
media busy book dalam meningkakan kemampuan berhitung anak usia dini. Sumber data dalam penelitian ini terdiri dari sumber data primer dan sumber data skunder (Sugiyono, 2015) sumber data primer dalam penelitian ini ialah peserta didik dan guru di TK THOYYIBAH. Sedangkan sumber skunder dalam penelitian ini ialah dokumen-dokumen yang berisikan lembar penilaian harian sampai dnegan bulanan peserta didik. Pemilihan jumlah sumber ini sangat berpengaruh dalam penelitian ini. Sehingga diharapkan sumber data tersebut dapat memberikan suatu informasi terkait implementasi pembelajaran mengunakan media busy book dalam meningkatkan kemampuan berhitung anak usia dini. Data dikumpulkan melalui tekhnik pengumpulan data dilakukan berbagai setting, berbagai sumber, dan berbagai cara. Tekhnik pengumpulan data yang digunakan dalam penelitian ini dilaksanakan wawancara, Observasi, dan Dokumentasi. Wawancara terhadap Pendidik dan Peserta didik.

\section{Kajian Teori}

\section{a. Perkembangan Kognitif}

Perkembangan kognitif adalah proses seorang individu dapat meningkatkan kemampuan dalam menggunakan pengetahuan. Terjadinya perkembangan kognitif dipengaruhi kematangan otak yang mampu menunjukan fungsinya secara baik, yang dapat digambarkan dengan kemampuan menerima dan menolak sesuatu (Emung Fatih, 2006). Faktor kognitif mempunyai peranan yang sangat bagi keberhasilan anak dalam belajar, karena sebagian aktivitas belajar berkaitang dengan mengingat dan berpikir. Kedua hal ini merupakan aktivitas kognitif perlu dikembangkan (H. E. Mulyasa, 2012). Perkembanganan anak secara normal berlangsung secara terus menerus-menerus dan mengikuti tahapan suatu perkembangan. Piaget mengelompokan tahapan perkembangan kognitif kedalam empat tahapan, yaitu: (a) tahap sensorimotor, (lahir-2 tahun) merupakan tahap pertama dalam perkembangan. Dalam tahap ini anak membangun pemahaman akan dunia dengan mengkordinasikan pengalaman sensoris (seperti melihat dan mendengar). Pada akhir tahap ini, anak umur 2 tahun sudah mulai menggunakan simbol-simbol sederhana. (b) tahap praoperasional (2-7 tahun), pada tahap ini 
anak-anak mulai menjelaskan duni mengunakan kata-kata, gambar, dan lukisan. (c) tahapan operasional kongkrit (7- 11 tahun) pada tahap ini anak dapat melakukan operasi dan menggatikan pikiran intutif sementara penalaran dapat diterapkan pada contoh kongkrit dan khusus. (d) tahap operasional formal yang muncul antara 11-15 tahun atau masa dewasa. Pada tahap ini individu lebih melampaui pengalaman kongkrit dan berfikir lebih abstrak atau logis (John W. Santrok, 2007).

Mekanisme utama yang memungkinkan anak berkembang dari satu tahap yang melibatkan fungsi kognitif terhadap tahab berikutnya iyalah: Pertama, asimilasi, yang merujuk pada usaha individu untuk menghadapi lingkungan dengan menyesuaikan ke dalam struktur organisme itu sendiri yang sudah ada dengan cara mengabungkanya. Kedua okomodasi, merupakan kecendrungan individu untuk berubah sebagai respon terhadap tuntas gagasan agar cocok dengan situasi, objek atau situasi baru. Kedua okomodasi, merupakan kecendrungan individu untuk berubah sebagai respons terhadap tuntuan gagasan agar cocok dengan situasi dan kondisi yang baru. Ketiga, ekulibrasi, usaha semua organisme untuk menyeimbangkan interaksi mereka dengan lingkungan. Piaget (ahmad susanto, 2012) berpendapat bahwa pentingnya guru mengebangkan kognitif pada anak bertujuan:

1) Agar anak mampu mengembangkan daya presepsinya berdasarkan apa yang dilihat, didengar dan dirasakan, sehinga anak memiliki pemahaman yang utuh dan komprehensif. 2) Agar anak mampu melatih ingatannya terhadap semua peristiwa dan kejadian yang pernah dialami. 3) Agar anak mampu mengembangkan pemikiran-pemikiran dalam rangka membangun satu peristiwa dengan peristiwa yang lainya. 4) Agar anak mampu memahami simbol-simbol yang tersebar di dunia sekitarnya. 5)Agar naka mampu melakukan penalaranpenalaran baik yang terjadi secara alamiah, maupun melalui proses ilmiah. 6) Agar anak mampu memecahkan persoalan hidup yang dihadapinya, sehinga anak akan menjadi individu yang mampu menolong dirinya sendiri.

Media ialah bentuk dan saluran yang dipergunakan untuk menyampaikan pesan dan informasi (M. Fadhilah, 2012). Media yang dipergunakan di lembaga pendidikan anak usia dini ialah berupa alat permainan edukatif. Menurut Kreasiumy Busy book 
merupakan sebuah buku yang dibuat dari kain flanel yang terdapat didalmnya berisikan gambar-gambar yang mempunyai tujuan untuk meningkatkan kreativitas anak, manfaat Busy book diberikan kepada anak usai dini ialah mampu merangsang rasa ingin tahu anak dengan cara menghibur, mendorong kemampuan motorik, keterampilan, mental dan emosional (Azra Aulia Ulfah, n.d.). melalui kegiatan bermaian mampu meningkatkan kemahiran berhitungnya, dikarenakan permainan mencocokan jumlah gambar yang terdapat di media busy book bisa melalui cara peserta didik menempel dan melepas dan mencocokan dengan angka yang sesuai sehingga memebentuk pohon yang dapat menarik minat anak.

\section{b. Media Busy Book}

Busy book ialah pengembangan dari buku edukatif. Busy book dibuat memakian kain berbahan flanel dengan banyak warna yang menarik dan kain yang tidak akan berbahaya untuk jangkauan anak-anak, mempunyai ukuran 25 x 25. Desain memakai media busy book ialah anak mengaplikasikan dengan cara mengancingkan, beberapa konsep lainnya seperti menghitung, menegnal ukuran, dan bentuk maupun warna dan menyatukan bentuk-bentuk angka dan huruf. (Sataloff et al., n.d.). Sejalan dengan pendapat zaman, dkk (Sataloff et al., n.d.) yang mempergunakan berbagai media pembelajaraan membutuhkan keterampilan tersendiri dan khusus. Dengan langkah buku mutlak yang dipergunakan oleh pendidik sebagai acuan pembelajaraan. Di era globalisasi pada saat ini yang dikembangkan ialah fun tinder, book, activity book, buku bantal, buku edukatif dan busy book. Menurut Gaity Busy book berisikan kegiatan sehari-hari. Selain membuat anak sibuk dengan adanya aktivitas yang bermakna, juga pengenalan pelajaran mandiri sejak anak masa golden age. Di dalam busy book, anak akan menemukan permainan-permainan unik yang menyenangkan yang akan mengasah kognitif peserta didik. (Gaiti, 2014). Sejalan dengan pendapat Mufliharsi Busy book merupakan media yang efektif untuk mengajarkan kosa kata sederhana secara menarik perhatian contohnya : animals, color, number, dan shape (Dwiyanti et al., 2019).

Busy Book ialah sebuah media pembelajaraan yang intersktif terbuat dari kain ( kain flanel) yang dibentuk menjadi sebuah buku dengan warna-warna cerah, berisi aktivitas permainan sederhana yang mampu merangsang kemampuan 
motorik halus anak seperti memasang kancing, mencockan warna atau bentuk, dan menjahit, biasana ditunjukan untuk anak usia pra sekolah.(Mufliharsi, 2017). Di dalam media busy book berisikan aktifitas-aktifitas sederhana seperti puzzle, maze, membuka reseleting menyatukan dan lain-lain. Busy book ini merupakan media yang efektif untuk mengajarkan kosa kata sederhana scara menarik antara lain : color, animals, numbers, dan shape. Selain mengajrkan kosakata, busy book juga mampu merangsang kognitif dan keterampilan halus (fine motor) anak usia dini, bentuk dari busy book terbuat dari kain, dan bentuknya yang mempunyai banyak warna akan menjadikan pembelajaraan tentang kosakata menjadi menyenangkan dan tentunya materi yang diajarkan mampu diserap oleh anak-anak.

Pembelajaran dengan memakai busy book mempunyai beberapa keunggulan, yakni : 1) Pendidik mudah menentukan materi pembelajaraan yang tunggal disesuaikan dengan perintah yang disesuaikan dengan perintah yang disesuaikan dengan perintah atau konsep yang ada di dalam busy book, 2) pendidik dapat dengan mudah mengevaluasi peserta didik karena dengan sendirinya aktivitas yang terdapat di dalam buku dapat mengeksplorasi kemmapuan masing-masing peserta didik. 3) peserta didk tanpa diminta, melakukan aktivitas yang dituntut dilakukan di dalam media busy book. 4) akan timbul rasa ingin tahu dari peserta didik dan cenderung langsung melakukan sendiri tanpa bantuan pendidik. 5) sifat media tahan lama karena terbuat dari kain yang cukup tebal dan tahan lama yang tidak gampang kotor, kusut maupun robek. 6) pembelajaraan dikelas menjadi menyenangkan dan aktif, 7) kegiatan belajar mengajar menjadi efektif dan aktif, 8) Pembelajaraan menjadi menyenangkan karena banyak warna, banyak aktiftas dan memancing kreatifitas peserta didik untuk melakukan aktivitas yang ada menjadi lebih efektif (Mufliharsi, 2017). Berhitung diperlukan untuk menumbuh kembangkan keterampilan berhitung yang sangat diperlukan dalam kehidupan sehari-hari, terutama konsep bilangan yang merupakan juga dasar bagi pengembangan kemampuan matematika keterampilan untuk mengikuti pendidikan dasar. (Depdiknas, 2007). Berhitung merupakan bagian dari matematika yang diperlukan untuk menumbuh kembangkan keterampilan berhitung yang sangat diperlukan bagi kehidupan 
sehari-hari, terutama konsep bilangan merupakan dasar bagi pengembangan kemampuan matematis.

\section{Hasil}

a. Perencanaan Pembelajaraan Media busy book

Perencanaan kegiatan belajar mengajar ialah Langkah awal yang harus dilakukan oleh pendidik sebelum melakasanakan belajar mengajar. Di dalam membuat suatu perencanaan pendidik membuat Rencana Pembelajaraan Mingguan (RPPM) setelah itu dikembangkan menjadi Rencana Pembeajaaraan Harian (RPPH) tersebut yang menjadi acuan pendidik untuk melaksanakan kegiata belajar mengajar. Berdasarkan hasil observasi dan wawancara yang dilakukan pada awal bulan Januari 2021. Pelaksanaan pertama dalam kegiatan pembelajaraan menunjukkan bahwa adanya peningkatan, namun peningkatan tersebut belum mencapai kriteria yang diharapkan atau pada kriteria sangat baik. Maka dari itu, penelitian akan dilihat pada pertemuan berikutnya dengan harapan dapat mencapai peningkatan yang optimal sesuai dengan indikator keberhasilan, yaitu anak dapat menghitung dan menullis angka yang sesuai dengan perhitungan buah, lalu anak bisa menyebutkan warna dan bentuk sesuai media papan busy book. Dari hasil pengukuran pada pertemuan pertama menunjukkan bahwa pencapaian daya ingat mengalami peningkatan dari setiap pertemuan. Daya ingat yang dimiliki peserta didik satu dengan anak yang lain berbeda-beda, ada yang mengalami peningkatan dan ada peserta didik yang hasilnya sama. Hasil tersebut dijadikan acuan oleh peneliti untuk melanjutkan penelitian selanjutnya dengan harapan seluruh indikator dapat mencapai peningkatan yang diharapkan dan sesuai dengan indikator keberhasilan, yaitu memiliki kriteria sangat baik. Adapun faktor yang mendukung anak cepat menguasai materi mengenal konsep bilangan adalah: Pembagian anak menjadi dua kelompok agar kegiatan pembelajaran menggunakan media busy book bisa berjalan dengan efektif, cara guru menyampaikan materi konsep bilangan dan memberikan penjelasan tentang media pembelajaran busy booknmenjadi point yang sangat penting, oleh karena itu perlu disiapkan RPPH agar pembelajaran bisa berjalan secara terstruktur sehingga keberadaan media pembelajaran menjadi tepat untuk mendukung penyampaian 
materi mengenal konsep bilangan pada anak. Setiap kegiatan pembelajaraan pendidik mengacu ada RPPH yang sesuai dengan pembelajaran berlangsung, ketertarikan anak terhadap media pembelajaran busy book menjadikan anak fokus dan antusias terhadap kegiatan yang diberikan, keaktifan anak berpartisipasi dalam setiap kegiatan selama proses pembelajaran, dan kerjasama dari wali murid yang meneruskan pembelajaran yang telah dilakukan disekolah dirumah dengan materi yang mudah dan ada disekitar anak ketika dirumah. Hal ini dikarenakan waktu anak lebih banyak dihabiskan dilingkungan rumah daripada disekolah.

Kegiatan awal pembelajaran yang menarik dapat memicu perhatian peserta didik kepada pendidik yang sedang menjelaskan materi pembelajaran. Hal ini disebabkan pada media busy book terdapat banyak bentuk yang mampu menstimulus aspek perkembangan anak sehingga mudah mengetahui tentang materi yang sedang dipelajari serta dapat memancing anak untuk aktif dalam berkata-kata. Selain itu peserta didik juga tetap mendengarkan penjelasan dari pendidik yang memicu indera pendengaran peserta didik. Menurut Gaity Busy book berisikan kegiatan sehari-hari. Selain membuat anak sibuk dengan adanya aktivitas yang bermakna, juga pengenalan pelajaran mandiri sejak anak masa golden age. Di dalam busy book, anak akan menemukan permainanpermainan unik yang menyenangkan yang akan mengasah kognitif peserta didik. (Gaiti, 2014).

Adapun permasalahan yang muncul selama proses pembelajaran pada pertemuan pertama, yaitu antara lain: (1) Peserta didik kesulitan menempatkan angka yang sesuai dengan lembar tugas, sebab peserta didik tidak melihat contoh atau ikut menghitung buah yang harus ditempelkan (2) Sebagian peserta didik mengerjakan dengan bekerja sama dengan teman yang lain, sehingga hasil perhitungan buah sama dengan temannya (3) Tidak semua peserta didik berminat dengan kegiatan mewarnai dan menghitung gambar,hanya mau bermian busy booknya saja sehingga peserta didik tersebut tidak menyelesaikan tugas. (4) Saat bermain anak-anak kadang memilih kelompok dan tidak mau menurut, (5) sebagian peserta didik hanya mau menentukan tema sendiri dan kadang masih banyak bertanya-tanya dan melanutkan cerita yang ada difikirannya sehingga memakan waktu yang cukup lama. 
Berdasarkan pelaksanaan yang telah dilakukan pada pertemuan pertama, melalui penggunaan media busy book dengan mewarnai gambar pola dan butiran mutiara pada busy book peserta didik yang berbeda dan pemberian kosa kata baru dapat meningkatkan kemampuan berhitung di TK Thoyyibah Bandar Lampung. Untuk itu pendidik akan memberikan rangsangan yang berupa motivasi dan reward pada setiap peserta didik agar menjadi lebih semangat. Suasana yang kondusif juga diciptakan oleh pendidik agar peserta didik menjadi nyaman saat mengerjakan tugas mengisi gambar dan saat melakukan pembelajarann mengunakan media busy book sehingga peserta didik mampu menjelaskan Kembali di depan teman-temannya dan menghitun lalu menyebutkan angka dan menyebutkan buah yang ditempelkan.

Pada pertemuan berikutnya peneliti dan pendidik menggunakan tema Tumbuhan dan subtema Makanan (Jenisjenis, Manfaat,makanan). Indikator pembelajaran pada pertemuan selanjutnya ini yaitu menghubungkan dan menyebutkan tulisan sederhana dengan gambar yang melambangkannya. Tugas peserta didik yaitu anak menarik garis dari tulisan nama gambar benda pada gambar benda yang sesuai kemudian mewarnai gambar yang termasuk jenis makananan seperti buah-buahan. Hasil pengamatan dapat dijelaskan bahwa pada saat peserta didik mengerjakan tugas mengisi gambar, dan peserta didik setelah mewarnai lanjut bermain dan menghitung buah lalu diwarnai sesuai telah disiapkan oleh pendidik. banyak peserta didik yang mulai mengurangi bertanya dan bercerita secara berulang-ulang kepada teman maupun pendidik. Peserta didik mulai terbiasa dengan media busy book dan gambar-gambar yang ditunjukkan oleh pendidik. Beberapa peserta didik mulai mampu mengingat beberapa gambar benda yang sesuai dengan subtopik pada media busy book seperti yang telah dijelaskan oleh pendidik.

Berdasarkan pengamatan pada pertemuan selanjutnya, hampir seluruh peserta didik dapat menjawab pertanyaan tentang media busy book dan nama benda pada media busy book. Semua peserta didik terlihat sudah terbiasa dengan media gambar yang ditunjukkan oleh pendidik. Kegiatan awal pendidik menerangkan tentang gambar dan nama pada media busy book, lalu peserta didik menjawabnya dengan lancar. Ada 
satu atau dua peserta didik yang masih hanya melihat media tanpa ikut menjawab seperti teman yang lain.

Evaluasi yang dilakukan terhadap peneliti dalam pelaksanaan pembelajaran pada pertemuan pertama. Hasil evaluasi selanjutnya dijadikan pijakan untuk pelaksanaan pembelajaran berikutnya. Hasil evaluasi menunjukkan bahwa proses pembelajaran dengan menggunakan media busy book dinilai dapat memberikan rangsangan untuk mengasah kemampuan kognitif anak dalam konsep berhitung. Hal ini disebabkan kegiatan mewarnai dan melihat gambar-gambar dengan menggunakan ingatan dan kemampuan anak berfikir. peserta didik dengan bimbingan pendidik dinilai cukup efektif untuk menarik perhatian peserta didik saat pendidik menerangkan pembelajaran dengan gambar-gambar yang berwarna-warni.

\section{b. Evaluasi Penanaman Konsep Berhitung}

Penilaian yang dilakukan oleh pendidik Ketika anak melakukan aktivtas belajar dengan mengunakan media busy book ialah proses yang dilakukan oleh anak dalam menyelesaikan permaianan dalam mengembangkan kemampuan berhitung anak. Penilaian ini sanagt berperan penting dilakukan oleh [endidik spaya dapat mengetahui perkembangan anak setiap harinya dengan kegiatan pembelajaraan setuap harinya. Berdasarkan observasi dan wawancara yang telah dilakukan oleh peneliti dalam Penggunaan Media busy book untuk meningkatkan kognitif berhitung anak. Guru melakukan evaluasi untuk melihat sejauh mana perkembangan konsep berhitung dan perkembangan berhitung anak. Evaluasi yang dilakukan oleh pendidik disaat kegiatan berlangsung yaitu dari proses yang dilakukan peserta ddik dalam mengaplikasikan media buy book yaitu disaat peserta didik mengambil tempelan buah yang terdapatpasangannya dan mencari pasangan Kembali dengan diawali dari angka 1-10.

Disaat peserta didik melakukan kegiatan berhitung di media busy book guru tetap mendampingi anak Ketika melakukan kegiatan dari awal sampai akhir, dengan adanya keikutsertaan guru. Guru dapat mengevalusi dan melihat langsung bagaimana kemampuan anak dalam berhitung. Kemmapuan anak dalam mencocokan kepingan buah angka 
yang terdapat di media busy book. Selain itu evaluasi yang dilakukan oleh guru dengan unjuk kerja anak Ketika kegiatan berlangsung yaitu guru menilai beberpa anak yang tetap aktif mengikuti kegiaatan permainan mmedia busy book, beberapa anak yang dapat melakukan kegiatannya sendiri da masih dibantu dengan teman maupun gurunya. Penilaian yang dilakukan oleh guru ialah menggunakan catatan lembar chek list setiap harinya, guna untuk menegtahi sampai mana perkembangan masing-masing anak.

Dengan adanya media yang menarik yang mampu mengembangkan kemampuan berhitung anak, karea pembelajaraan berhitung itu sanagat penting ditanamkan di dalam diri anak. (Yanti, S.D., Turdjai \& Kurniah, 2017) mengatakan bahwa kemampuan berhitung perlu diajarkan sejak dini, dengn berbagai metode dan media yang tepat karna usia 4-5 tahun belum dapat melakukan kegiatan berhitung ddengan sesunguhnya (berhitung bilangan abstark). Pemahaman konsep berhitung kepada anak perlu diberikan sejak dini mengunakan cara yang mudah dimengerti oleh anak(Reswita, 2018). Berhitungmerupakan kegiatan untuk anak usai dini yang disebut juga sebagai kegiatan menyebutkan urutan bilangan(Malapata, E., \& Wijayaningsih, 2019). (Farihah, 2017) Berhitung merupakan salah satu kemampuan sanagt penting bagi anak yang perlu dikembngkan dalam rangka membekali anak dikehidupan selanjutnya. Mengingat betapa pentingnya dalam kemapuan kognitif anak terutama dalam berhitung maka dari sejak dini perlu diajarkan dan mengasah kemampuan anak melalui mediametode yang tepat dalam mengasah pola perkemabangan anak Menurut pencockan dalam kemampuan berhitung misalnya pada konsep anak belajar untuk emngamati dan mengungkapkan lebih banyak persamaan hingga kosnep lebih banyak atau lebih sedikit. (Smith, 2009) berhitung yang dapat dlakukan mengunakan perhitungan lisan dengan cara berfikir yaitu membanca angka, mencocokan nomor ke satu set, emiliki nuansa intiutif untuk seberapa besar angka, membuat tebakan yang masuk akal menggunakan angka, dan melihat hubungan Sebagian-sebagian dengan karakteristik tersendiri sesuai dengan karakteristik tersendiri sesuai dengan tahapan usaianya. Masa usia (06tahun) masa keemasaan (golden age) dimana stimulasi 
seluruh aspek perkembangan berperan penting untuk tugas perkembangan selanjutnya.

Berdasarkan hasil pengamatan diatas secara keseluruhan pencapaian pengenalan dalam konsep berhitung telah mencapai sebanyak 97,1\% yang termasuk dalam kriteria sangat baik (81\%-100\%). Penilaian tersebut dilakukan dengan mengumpulkan rekapitulasi lembar penilaian peseta didik dari harian dan mingguan serta penilaian bulanan. Peningkatan ini terjadi meskipun ada perbedaan pada pertemuan pertama dan berikutnya yaitu pada gambar lembar tugas mewarnai dan media busy book. Hal ini menunjukkan bahwa peserta didik di TK THOYYIBAH Bandar Lampung Baru tidak hanya mampu berhitung dan juga sudah mampu melafalkan bilangan angkaangka yang terdapat di media busy book, selain meningkatkan kemampuan kognitif anak dalam mengenal konsep bilangan terdapat banyak sekali manfaat lain yang didapat oleh peserta didik, bukan hanya kemampuan kognitifnya namun banyak aspek perkembanan lain yang ikut terstimulus dalam media busy book diantaranya: perkembangan sosial emosional dalam anak melakukan kegiatan bekerja sama dengan temantemannya, perkembangan motoric halus peserta didik mampu mengaplikasikan jari-jarinya dengan menempel tempelan gambar dan perkembangan kognitif anak dalam mengenal warna dan mengasah kemampuan anak dalam memecahkan masalah. 
$\cong \quad$ ThufuLA: Jurnal Inovasi Pendidikan Guru Raudhatul Athfal | 151

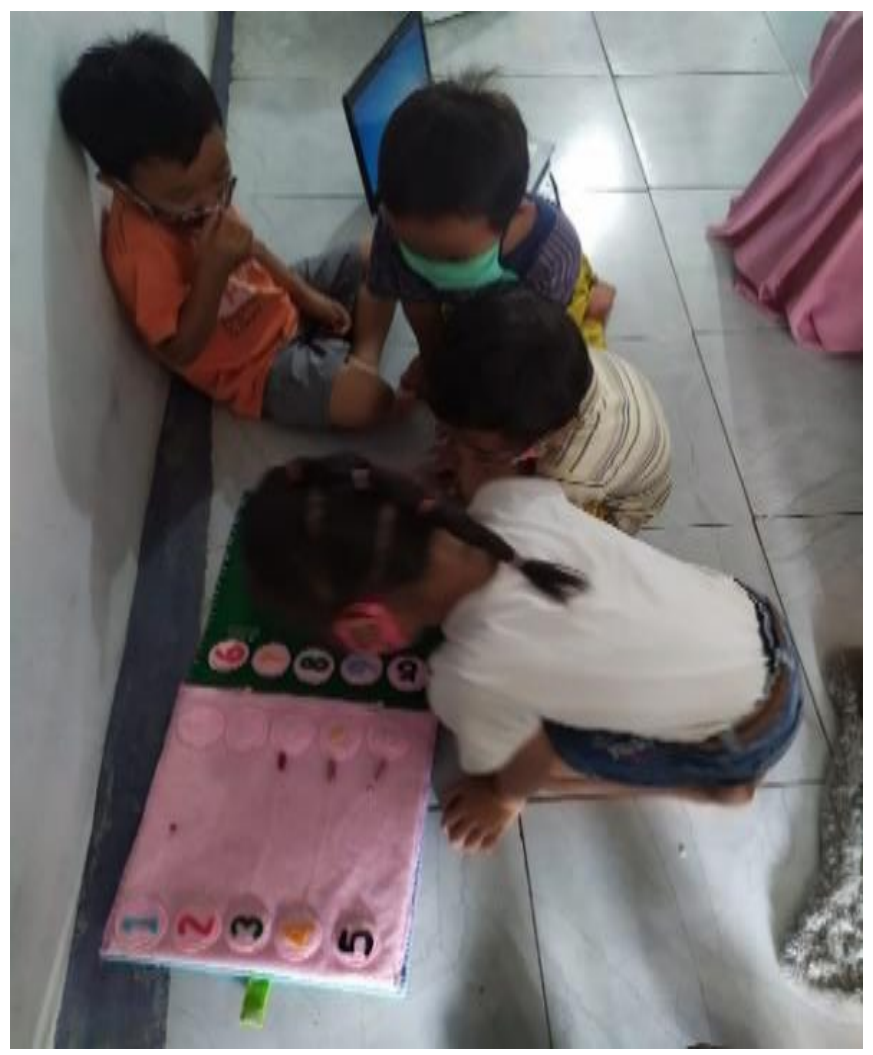

Gambar 1.1 
152 | Rifka Toyba Humaida, Muhammad Zainal Abidin

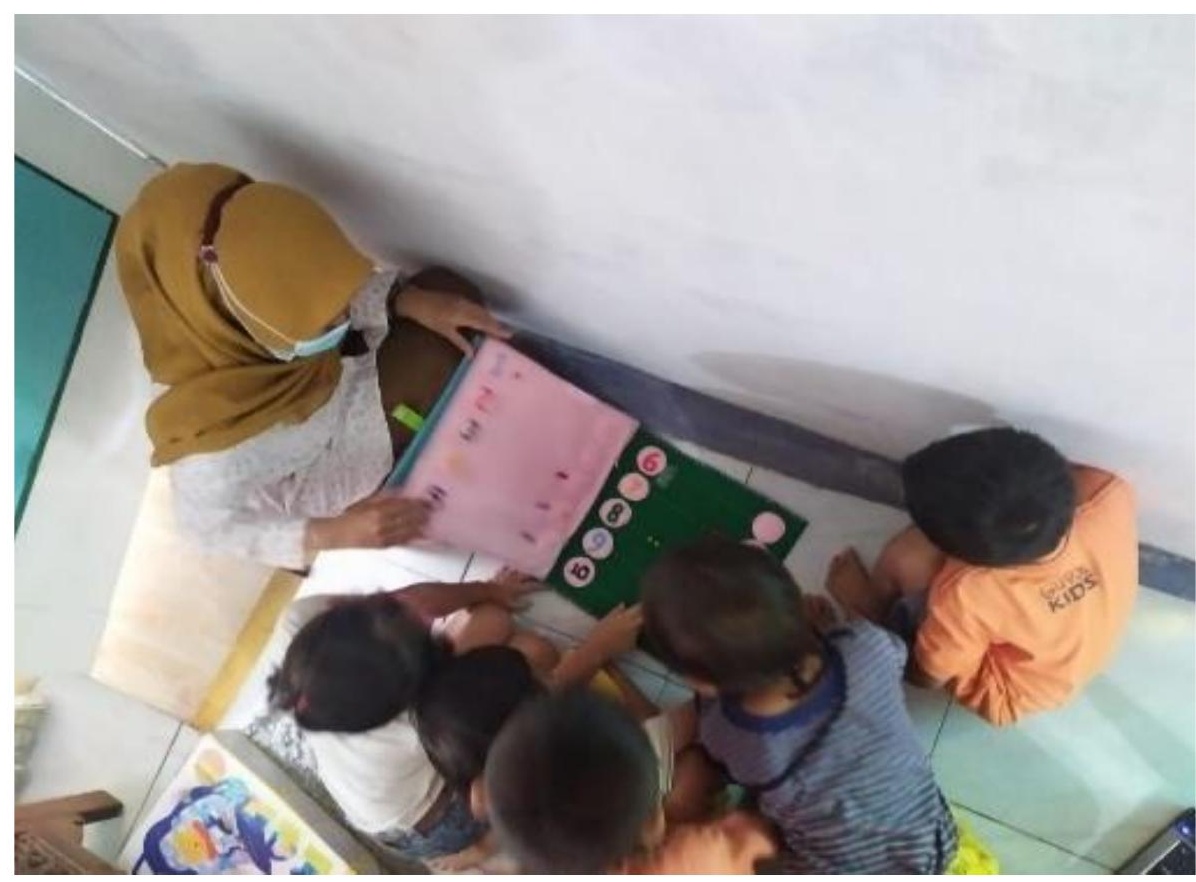

Gambar 1.2

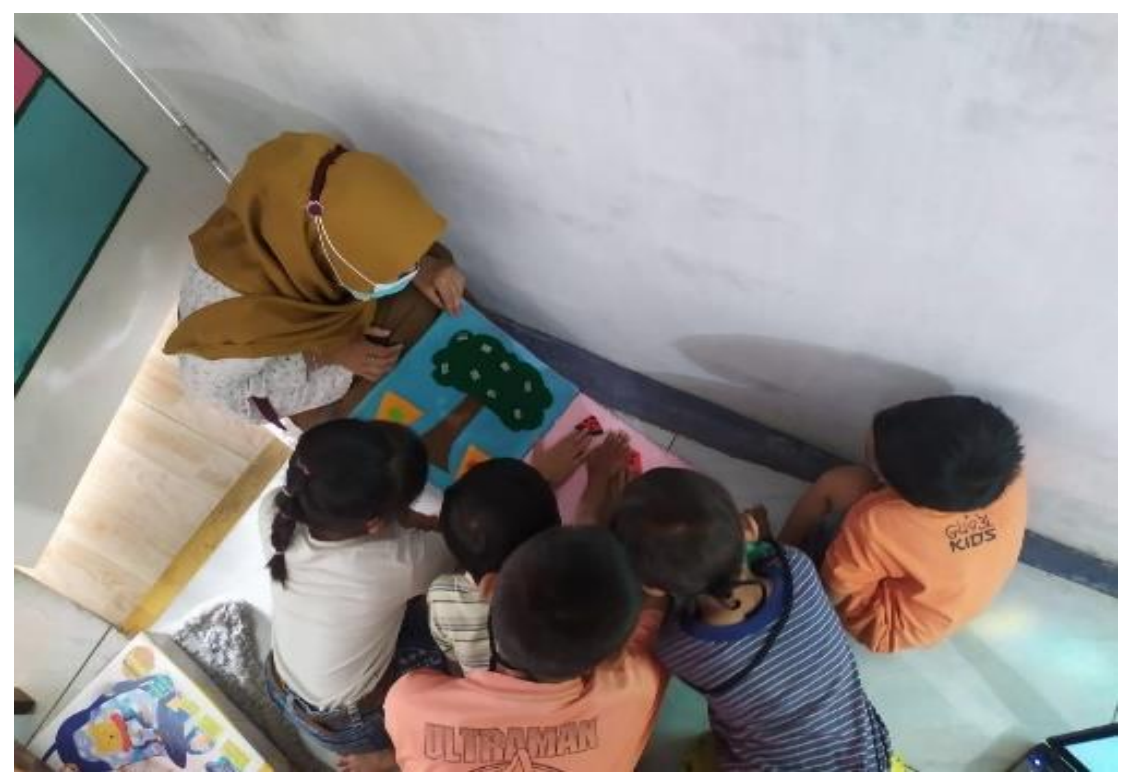




\section{Gambar 1.3}

Dapat dipahami bahwa penggunaan media Busy Book ini cocok sebagai alat bantu kegiatan pembelajaraan dalam menanamkan konsep berhiting anak untuk merngsang dan menstimulus fikiran, perasaan, dan membantu anak menyelesaikan masalah melalui kegiatan bermain. Berdasarkan paparan diatas dapat dipahami bahwasannya kegiatan pembelajaraan mengunakan media busy book yang melibatkan peserta didik aktif dan solutif. Dari berbagai refrensi, penulis menemukan model pembelajaraan media busy book ini sudah mulai diterapkan dalam beberapa Lembaga Pendidikan anak usia dini, berdasrkan temuan penelitian terdahulu yang penulis temukan ialah berisikan pembahasan untuk meningkatkan bahasa dan motorik halus anak saja, seperti yang dinyatakan oleh lela Nurlela bahwasanya pembelajaran busy book ini memberikan peningkatan Bahasa anak usia dini (LELA NURLELA, 2018). Dan yang selanjutnya Jurnal yang ditulis oleh Aninda Manuella yang berjudul Peerapan Permainan Busy Book Terhadap Kemampuan Motorik halus anak Autis Penelitian ini memiliki persamaan pada media pembelajaran yaitu busy book akan tetapi penelitian ini memilki perbedaan pada pencapaian perkembangan dan objek yang akan diteliti yaitu perkembangan kognitif dan objek yang akan diteliti yaitu anak tunarungu di TKLB YPPALB Putra Mandiri Kota Magelang. Berdasarkan dari beberapa jurnal yang diperoleh penulis, Media Busy Book sudah mulai diterapkan di pembelajaran Pendidikan Anak Usia Dini. Karna media busy book mampu untuk mengembangkan beberapa aspek perkembangan anak usia dini.

\section{Simpulan}

Pada dasarnya setiap anak terlahir sebagai anak yang cerdas, kreatif, namun apabila diberikan stimulus dan treatment yang baik oleh seorang pendidik dan orang tua maka kemampuan berhitng anak akan lebih berkembang sesuai dengan tahap usia anak. Dalam mengembangkan kemampuan kognitif anak terutama dalm berhitung dan membilang anak dilakukan di Taman Kanak-Kanak Thoyyibah dengan mengunakan media buys book Berdasarkan Pelaksanaan pembelajaran dengan mengggunakan media pembelajaran busy book Dengan hasil pembelajaran yang dilaksanakan di 
kelompok TK Thoyyibah dalam kegiatan pengembangan kognitif anak dalam mengenal konsep bilangan ini pada anak usia 4-5 tahun sudah Meningkat Terlihat dari hasil observasi terakhir yang dilakukan setelah penerapan media pembelajaran busy book, dimana terdapat peningkatan pada kemampuan kognitif anak dalam mengenal konsep bilangan dengan menggunakan media pembelajaran busy book. Maka dapat disimpulkan penggunaan media busy book efektif untuk di gunakan di PAUD.

\section{Referensi}

Ahmad susanto. (2012). Perkembangan Anak Usia Dini. Arikunto, S. (2011). Prosedur Penelitian. Rineka Ciptra. Azra Aulia Ulfah. (n.d.). "Pembuatan Dan Pemanfaatan Busy Book Dalam Mempercepat Kemampuan Membaca Untuk Anak Usia Dini Di PAUD Budi Luhur Padang. Jurnal Ilmu Informasi Perpustakaan Dan Kearsipan, vol, 6. No, 6.

Daryanto. (2011). Media Pembelajaran. PT. Sarana Tutorial Nurani Sejahtera.

Depdiknas. (2007). Permainan Berhitung di Taman kanakKanak. depdiknas.

Dwiyanti, L., Khan, R. I., \& Kurniawati, E. (2019).

Pengembangan Permainan Smart Adventure Untuk

Meningkatkan Kesiapan Belajar Berhitung Permulaan Anak Usia Dini. JIV-Jurnal Ilmiah Visi, 14(1), 59-66.

https://doi.org/10.21009/jiv.1401.6

Ecular, M. O. L., Ulation, S. I. M., The, O. N., Characteristics, D. I., Uene, T. O. L., Reactants, D. I., Ucts, P., The, I. N., Of, C., Series, Z. S. M., \& Ites, Z. (2010). , † 1 , ii "> 2 100083). 8719(2006). Emung Fatih. (2006). Psikologi Perkembangan Peserta didik.

Pustaka Setia Bandung.

Farihah, H. (2017). Mengembangkan Kemampuan Berhirun

Anak Usia Dini Melalui Kegiatan Bermain Stick Angka. Jurnal Teladan, 2((1)), 2-20.

Gaiti, F. (2014). Mainan Edukasi dari Flanel. In Tiara Aksa. H. E. Mulyasa. (2012). Manajemen PAUD. Remaja Rosdakarya. Hasyim, S. L. (2015). Pendidikan Anak Usia Dini (PAUD) dalam

Perspektif Islam. Jurnal Lentera: Kajian Keagamaan,

Keilmuan Dan Teknologi, vol, 1 No., 217-266. John W. Santrok. (2007). Perkembangan Anak. Erlangga. Kementrian Pendidikan Nasional RI. (2014). Standar Nasional 
Pendidikan Anak Usia Dini No 137 Tahun 2014. Peraturan Menteri Pendidikan Dan Kebudayaan Republik Indonesia, 176. https://portaldik.id/assets/upload/peraturan/PERMEN KEMENDIKBUD Nomor 137 Tahun 2014 STANDAR NASIONAL PENDIDIKAN ANAK USIA DINI.pdf

LELA NURLELA. (2018). PENGEMBANGAN MEDIA PEMBELAJARAN BUSY BOOK DALAM MENINGKATKAN KEMAMPUAN BAHASA ANAK USIA DINI DI PLAY GROUP ISLAM BINA BALITA WAY HALIM BANDAR LAMPUNG TAHUN AJARAN 2017/2018. 3.

M. Fadhilah. (2012). Bermain dan Permainan Anak Usia Dini.

Malapata, E., \& Wijayaningsih, L. (2019). meningkatkan Kemampuan Berhitung Anak Usia 4-5 Tahun Melalui m=Media Lumbung Hitung. Jurnal Obsesi : Jurnal Pendidikan Anak Usia Dini, 3((1)), 183.

Mufliharsi, R. (2017). Pemanfaatan Busy Book pada Kosakata Anak Usia Dini di PAUD Swadaya PKK. Jurnal Metamorfosa, $V$ (May), 146-155.

Nurfadillah, R. R., \& Rakhman, A. (2020). IMPLEMENTASI METODE STEAM BERBASIS MEDIA FILM DALAM MENINGKATKAN ASPEK KOGNITIF PADA PENDIDIKAN ANAK USIA DINI. 3(3), 266-274.

Reswita, \& W. S. (2018). Efektivitas Media Pasir dalam Meningkatkan Kemampuan Konsep Bilanagn Pada Anak usia 5-6 Tahun di TK aisyihan Bengkalis. Jurnal Pendidikan, $9((1)), 927$.

Sataloff, R. T., Johns, M. M., \& Kost, K. M. (n.d.). No 主観的健康 感を中心とした在宅高齢者における健康関連指標に関す る共分散構造分析Title. 229.

Smith, S. . (2009). Early Chilhood Mathematics. Pearson : America.

Sugiyono. (2015). Metode Penelitian Pendidikan. Alfabeta.

Wasik, sefeel. (2008). Pendidikan Anak Usia Dini. Indeks.

Wiyani, N. A. (2014). Psikologi Perkembanagan Anak Usia Dini. Gava Media.

Yanti, S.D., Turdjai \& Kurniah, N. (2017). Penerapan Metode Bermain Sensorimotor untuk Meningkatkan Kogitif dan Motorik Halus Anak (Studi Pada Anak Kelompok A1 PAUD Negeri Pembina 1 Kota Bengkulu). Jurnal Ilmiah Teknologi Pendidikan, 7((2)), 71-77.

Yuliani Nuraini Sujiono. (2013a). Konsep Dasar Pendidikan 
156 | Rifka Toyba Humaida, Muhammad Zainal Abidin

Anak Usia Dini (Yuliani Nuraini Sujiono (ed.); 7th ed.). Indeks.

Yuliani Nuraini Sujiono. (2013b). Konsep Dasar Pendidikan Anak Usia Dini (Bambang Sarwaji (ed.); 7th ed.). Indeks. 